\title{
Temporal variation of microbial population in a thermophilic biofilter for $\mathrm{SO}_{2}$ removal
}

\author{
Jingying Zhang, Lin Li*, Junxin Liu \\ Research Center for Eco-Environmental Sciences, Chinese Academy of Sciences, Beijing 100085, China. E-mail: zhangjingying123@126.com
}

\section{A R T I C L E I N F O}

Article history:

Received 25 July 2015

Revised 2 November 2015

Accepted 4 November 2015

Available online 17 December 2015

Keywords:

Thermophilic biofilter

Sulfur dioxide

Microbial population

DGGE analysis

$\mathrm{O}_{2}$ distribution

\begin{abstract}
A B S T R A C T
The performance of a biofilter relies on the activity of microorganisms during the gas contaminant treatment process. In this study, $\mathrm{SO}_{2}$ was treated using a laboratory-scale biofilter packed with polyurethane foam cubes (PUFC), on which thermophilic desulfurization bacteria were attached. The thermophilic biofilter effectively reduced $\mathrm{SO}_{2}$ within 10 months of operation time, with a maximum elimination capacity of $48.29 \mathrm{~g} / \mathrm{m}^{3} / \mathrm{hr}$. Temporal shifts in the microbial population in the thermophilic biofilter were determined through polymerase chain reaction-denaturing gradient gel electrophoresis and deoxyribonucleic acid (DNA) sequence analysis. The substrate species and environmental conditions in the biofilter influenced the microbial population. Oxygen distribution in the PUFC was analyzed using a microelectrode. When the water-containing rate in PUFC was over $98 \%$, the oxygen distribution presented aerobic-anoxic-aerobic states along the test route on the PUFC. The appearance of sulfate-reducing bacteria was caused by the anaerobic conditions and sulfate formation after 4 months of operation.

(C) 2015 The Research Center for Eco-Environmental Sciences, Chinese Academy of Sciences.
\end{abstract}

Published by Elsevier B.V.

\section{Introduction}

Sulfur dioxide $\left(\mathrm{SO}_{2}\right)$ emission from industrial processes, especially fossil fuel combustion, is widely regarded as a risk to the atmospheric environment and human health (Weerasinghe, 2010). High levels of $\mathrm{SO}_{2}$ are particularly dangerous in the presence of particulate matter, because it slowly adsorbs onto fine atmospheric particles and can be transported very deep into the lungs, therefore staying there for a long time (Nasir and Brahmaiah, 2015). Various technologies, including physicalchemical (scrubbing, adsorption, incineration, and masking) and biological methods have been applied in $\mathrm{SO}_{2}$ removal (Ralebitso-Senior et al., 2012). Low operating costs, convenient maintenance, and environmental friendliness are the advantages of bio-techniques for off-gas treatment (Van Groenestijn and Hesselink, 1993; Yang et al., 2008). The bioreactor principle is based on passing the polluted air stream through a porous packed bed on which pollutant-degrading microorganisms form an active biofilm on the surface of the packing materials. The pollutant in the air stream is transferred from the gas phase into the biofilm, where it can be biodegraded (Mohammad et al., 2007). Recently, Saravanan et al. (2015) found that xylene vapor could be removed up to $99 \%$ by using two biofilters which were packed with pressmud, proving the effectiveness of biofilters in treating polluted air.

Microorganisms in a bioreactor play important roles in the gas contaminant treatment process. Several groups of microorganisms, primarily bacterial species, are responsible for the degradation of air pollutants in biofilters (Reynolds and Grafton, 1999). Thiobacillus thioparus, Bacillus sp., and Pseudomonas sp. have been applied widely in the removal of sulfur-containing compounds from waste streams (Degorce-Dumas et al., 1997;

\footnotetext{
* Corresponding author. E-mail: leel@rcees.ac.cn (Lin Li).
} 
Ho et al., 2008; Ryu et al., 2009). Various factors influence the growth kinetics of participating microorganisms, including substrate concentration, moisture content, temperature, oxygen transfer, $\mathrm{pH}$, and availability of mineral nutrients (Ottengraf, 1986; Sakuma et al., 2008; Beuger and Gostomski, 2009; Jiang et al., 2012).

The microbial population growth rate depends on the temperature in the biofilter, which in turn affects biodegradation kinetics. William and Miller (1992) studied the influence of temperature on microorganism activity and found that biological activity roughly doubles for each $10^{\circ} \mathrm{C}$ rise in temperature of the biofilter bed. When the temperature in the biofilter was less than $25^{\circ} \mathrm{C}$ or over $50^{\circ} \mathrm{C}$, a marked decrease occurred in the hydrogen sulfide $\left(\mathrm{H}_{2} \mathrm{~S}\right)$ removal efficiency, which was caused by a decline in sulfur oxidation bacteria (Yang and Allen, 1994). The application of thermophilic microorganisms for the treatment of off-gas at over $50^{\circ} \mathrm{C}$ would increase elimination rates and the desired efficiency would be achieved at shorter reaction times or a smaller reactor volume (Kong et al., 2001). Another advantage of thermophilic operation is a decrease in the biomass yield and its accumulation in the biofilter bed, which normally causes bed clogging and pressure drop through the bed. Various studies on thermophilic operation of gas phase bioreactors $\left(45^{\circ} \mathrm{C}-75^{\circ} \mathrm{C}\right)$ for the treatment of odor compounds have been reported recently (Cox et al., 2001; Mohammad et al., 2007; Zhang et al., 2015).

The microorganism community in the biofilters uses the contaminants in off-gas as food or substrate, and such contaminants serve as their energy source and building material. The microbial population relies on substrate concentration and species (Devinny et al., 1999). For $\mathrm{H}_{2} \mathrm{~S}$ treatment in a bench biofilter, high contaminant concentration can adversely affect microbial populations. $\mathrm{H}_{2} \mathrm{~S}$ is toxic to microbes at higher concentrations. Additionally, sulfuric acid is formed as $\mathrm{H}_{2} \mathrm{~S}$ is degraded, reducing the medium $\mathrm{pH}$. This declining $\mathrm{pH}$ eventually inhibits the performance of the biofilter (Allen and Yang, 1991). When complex compounds are treated in succession, toxic shock to the microbes may interrupt degradation until an adapted microbial population develops (Baltzis and Androutsopoulou, 1994).

Microorganisms obtain energy for their growth via aerobic respiration in the presence of oxygen, which is abundant in an environment fully exposed to air. In most cases, biofilters for off-gas treatment are aerobic, making them suitable for aerobic microorganisms. Facultative anaerobic or anaerobic microorganisms are abundant in environments with an oxygen volume fraction of less than $2 \%$ (Lee et al., 2001). With the innovation of microelectrodes, detection of the oxygen distribution in microenvironments is now possible and interesting oxygen microelectrode studies have been performed, including in nitrifying/denitrifying biofilms (Stief et al., 2003) and a single floc (Tsai et al., 2008; Han et al., 2012). Microelectrode measurements provide reliable and in situ information on the activity of microorganisms in biofilms formed on media (Chae et al., 2012). However, little is known about oxygen detection via microelectrodes on packing media for off-gas treatment to date.

In the current study, high-temperature $\mathrm{SO}_{2}$ was treated with a laboratory-scale biofilter containing thermophilic desulfurization bacteria. Polyurethane foam cubes (PUFC) were packed in the thermophilic biofilter for immobilizing the microorganisms. The polymerase chain reaction denaturing gradient gel electrophoresis (PCR-DGGE) method was applied to explore the characteristics and temporal variation of the bacterial population in the biofilter. Microelectrodes were used to analyze the oxygen distribution in PUFC. The relationship between microbial characteristics and oxygen distribution was also explored in the thermophilic biofilter.

\section{Experimental}

\subsection{Experiment and processes}

A thermophilic biofiltration system was set up for $\mathrm{SO}_{2}$ elimination treatment (Fig. 1). The stainless steel biofiltration column had a height of $30 \mathrm{~cm}$ and a diameter of $10 \mathrm{~cm}$. The packing material for thermophilic bacteria attachment was PUFC $\left(1.0 \mathrm{~cm}^{3}\right) . \mathrm{SO}_{2}$ synthesis, supplementation, and control methods were described in a previous report (Zhang et al., 2015). The synthetic gas was made of $\mathrm{SO}_{2}$ and $\mathrm{N}_{2}$, with a $\mathrm{SO}_{2}$ concentration of $1 \%$. The synthetic gas was diluted by air to certain concentrations before passing into the biofilter. The total flow rate controlled by a mass flow meter, which was calibrated in advance, was $0.6 \mathrm{~m}^{3} / \mathrm{hr}$ and corresponded to an empty bed residence time of $18 \mathrm{sec}$. The biofilter was inoculated with microorganisms to accelerate the startup period. The packing medium collected from the bioreactor for treating sulfur-containing compounds was used as inoculums and soaked in a nutrient solution, which contained beef extract of $5 \mathrm{~g} / \mathrm{L}, \mathrm{K}_{2} \mathrm{HPO}_{4}$ of $2.0 \mathrm{~g} / \mathrm{L}, \mathrm{KNO}_{3}$ of $2.0 \mathrm{~g} / \mathrm{L}, \mathrm{FeCl}_{2} \cdot 4 \mathrm{H}_{2} \mathrm{O}$ of $0.01 \mathrm{~g} / \mathrm{L}, \mathrm{NaHCO}_{3}$ of $1.0 \mathrm{~g} / \mathrm{L}, \mathrm{MgCl}_{4} \cdot 6 \mathrm{H}_{2} \mathrm{O}$ of $0.1 \mathrm{~g} / \mathrm{L}, \mathrm{NH}_{4} \mathrm{Cl}$ of $0.5 \mathrm{~g} / \mathrm{L}$ and $\mathrm{Na}_{2} \mathrm{~S}_{2} \mathrm{O}_{3} \cdot 5 \mathrm{H}_{2} \mathrm{O}$ of $5.0 \mathrm{~g} / \mathrm{L}$ (pH 6.5 to 7.0). The nutrient solution with medium was then shaken for $30 \mathrm{~min}$ in an ultrasonic oscillator (KQ-250B, Kunshan, China). The liquid with suspended cells was cultured in the same nutrient solution at $60^{\circ} \mathrm{C}$ and $120 \mathrm{r} / \mathrm{min}$ for 4 weeks to enrich the microorganisms able to degrade $\mathrm{SO}_{2}$. Sampling ports were set along the biofilter for sample collection. $\mathrm{SO}_{2}$ concentrations before and after the treatment were determined by samples 1 and 3, whereas sample 2 for PUFC collection was used for microbiological analysis (Fig. 1). A mineral nutrient solution consisting of $5 \mathrm{~g} / \mathrm{L}$ beef extract, $2.0 \mathrm{~g} / \mathrm{L} \mathrm{K}_{2} \mathrm{HPO}_{4}, 2.0 \mathrm{~g} / \mathrm{L} \mathrm{KNO}_{3}$, $0.01 \mathrm{~g} / \mathrm{L} \mathrm{FeCl}{ }_{2} \cdot 4 \mathrm{H}_{2} \mathrm{O}, 1.0 \mathrm{~g} / \mathrm{L} \mathrm{NaHCO} 3,0.1 \mathrm{~g} / \mathrm{L} \mathrm{MgCl} \cdot 6 \mathrm{H}_{2} \mathrm{O}$, and $0.5 \mathrm{~g} / \mathrm{L} \mathrm{NH}_{4} \mathrm{Cl}$ was periodically sprayed into the biofilter to supply nutrients and sustain moisture above $80 \%$. The used nutrient solution was drained from the bottom of the biofilter.

\subsection{Chemical analysis}

A flue gas analyzer (rbr, Ecom-J2KN, Germany) was used to monitor $\mathrm{SO}_{2}$ online. An ion chromatogram analyzer was utilized to analyze sulfate concentrations in the liquid phase (ICS-1000, Dionex ion chromatography system, USA). Samples were diluted and filtered before injecting a volume of $1.0 \mathrm{~mL}$. Gravimetry determined the water-containing rate (WCR) of the packing material. The temperature in the biofilter was recorded using a Dewpoint Thermohygrometer (WD-35612, OAKTON, Germany) sustained at $40^{\circ} \mathrm{C}-60^{\circ} \mathrm{C}$. A pH meter ( $\mathrm{pH}-3 \mathrm{C}$, Shanghai, China) was used to detect the $\mathrm{pH}$ values. 


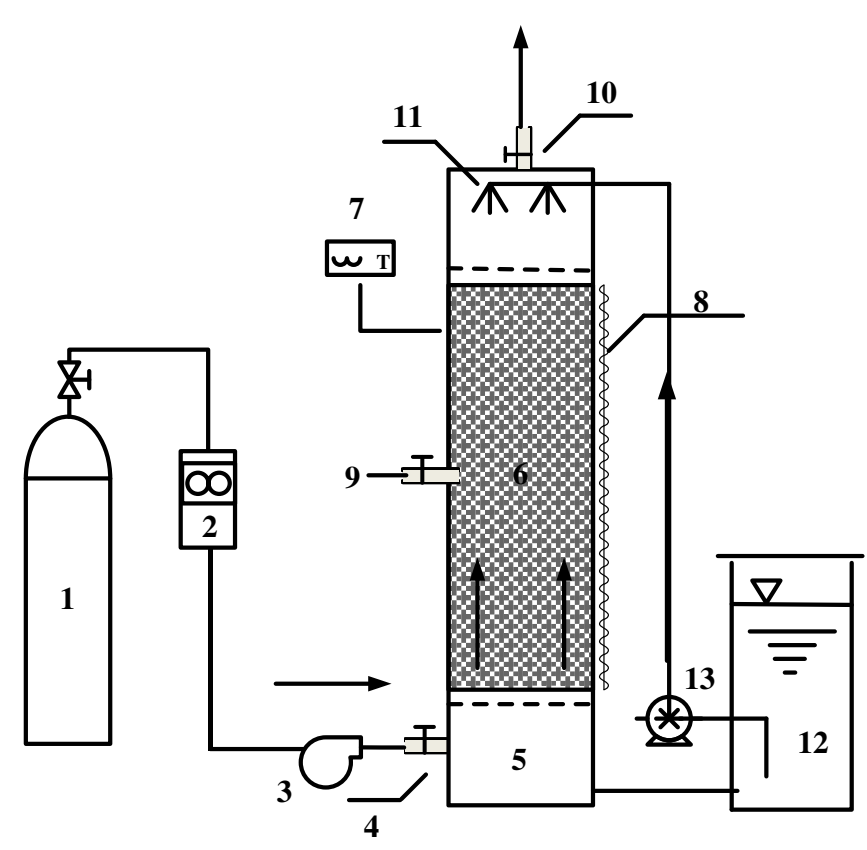

Fig. 1 - The schematic diagram of the thermophilic biofilter. 1: high-pressure cylinder; 2: mass flow meter; 3: air pump; 4: sample 1: inlet sampling point; 5: biofiltration column; 6: packing layer; 7: thermostat; 8: heating layer; 9: sample 2: packing sampling point; 10: sample 3: outlet sampling point; 11: sprinkler; 12: circulating pool; and 13: water pump.

\section{3. $\mathrm{O}_{2}$ distribution in PUFC}

The $\mathrm{O}_{2}$ distribution on PUFC was measured using a microelectrode with a tip diameter of $10 \mu \mathrm{m}$ (OX-10, Unisense, Denmark). PUFC with a range of WCR were investigated in the present study. $\mathrm{O}_{2}$ determination began at point $\mathrm{A}$ and stopped at point $B$ (Fig. 2). The entire detection length on the PUFC was $12,000 \mu \mathrm{m}$, with a step of $100 \mu \mathrm{m}$.

\subsection{Microbiological analysis}

Electron microscopy was used to observe the PUFC and biofilms of microorganisms in the packing material. Samples were fixed with $2.5 \%$ glutaraldehyde for $4 \mathrm{hr}$, washed thrice

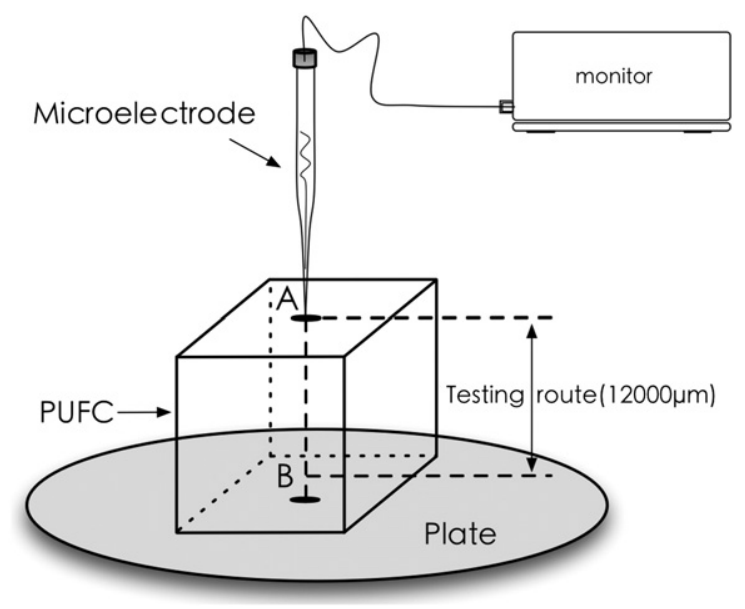

Fig. 2 - The schematic diagram of oxygen detection using microelectrodes. with phosphate buffer for 15-20 min at each time, and fixed with $1 \% \quad \mathrm{OsO}_{4}$ for $2-4 \mathrm{hr}$. Samples were then washed thrice with the same buffer prior to dehydration in a graded alcohol series $(30 \%-100 \%)$ for $15 \mathrm{~min}$. Finally, samples were dried with a critical point dryer (CPD 030) and coated with gold. Observation of samples was performed with a scanning electron microscope (HITACHI SU-8020/EDAX Inc., Japan)

The bacteria were incubated in a nutrient agar (BR, Aoboxing Biotech, Co., China) at $60^{\circ} \mathrm{C}$ for $24 \mathrm{hr}$. Sulfur bacteria were cultivated in a medium containing $2.0 \mathrm{~g} / \mathrm{L} \mathrm{K}_{2} \mathrm{HPO}_{4}, 2.0 \mathrm{~g} / \mathrm{L} \mathrm{KNO}_{3}$, $0.01 \mathrm{~g} / \mathrm{L} \mathrm{FeCl} 2 \cdot 4 \mathrm{H}_{2} \mathrm{O}, 1.0 \mathrm{~g} / \mathrm{L} \mathrm{NaHCO}{ }_{3}, 0.1 \mathrm{~g} / \mathrm{L} \mathrm{MgCl}_{4} \cdot 6 \mathrm{H}_{2} \mathrm{O}, 0.5 \mathrm{~g} / \mathrm{L}$ $\mathrm{NH}_{4} \mathrm{Cl}$, and $5.0 \mathrm{~g} / \mathrm{L} \mathrm{Na}_{2} \mathrm{~S}_{2} \mathrm{O}_{3} \cdot 5 \mathrm{H}_{2} \mathrm{O}$ at $60^{\circ} \mathrm{C}$ for 3 days. Cell counts were reported as colony-forming units (CFUs).

Total DNA was directly extracted using an Activated Sludge DNA Automatic Plate form for Magnetic System-16 (TanBead, Taiwan). Next, 1.0\% agarose gel electrophoresis (Bio-Rad, USA) was applied to determine DNA bands. PCR was conducted using a C1000TM thermal cycler (Bio-Rad, USA). Specific universal primers, such as F357 with a GC clamp and R517 (F357GC: 5'-CGCCCGCCGCGCGCGGCGGGCGGGGCGGGGGCACGGGGGGCCTACGGGAGGCAGCAG-3' and R517: 5'-ATTACCGCGGCTG CTGG-3'), were used to amplify the V3 regions of the bacterial $16 \mathrm{~S}$ ribosomal RNA gene of the microbial samples collected from the thermophilic biofilter. Denaturing gradient gel electrophoresis (DGGE) was performed on $6 \%$ to $12 \%$ (W/V) polyacrylamide gel with $40 \%$ to $70 \%$ denaturing gradient. Electrophoresis was performed in a $1 \times$ Tris-acetate-EDTA buffer at $60^{\circ} \mathrm{C}$ and a constant voltage of $65 \mathrm{~V}$ for $16 \mathrm{hr}$ using a Bio-Rad DCode system (DCode, Bio-Rad, USA). Bacterial diversity was determined according to the intensity and number of bands using the Shannon index $(H)$. Sequences were edited to exclude the priming site, and were then compared with 
sequences available in the GenBank database using a nucleotide-nucleotide BLAST algorithm. Detailed procedures were described in our previous report (Li et al., 2012; Zhang et al., 2015).

\section{Results and discussion}

\subsection{Performance of the thermophilic biofilter}

The thermophilic biofilter operated continually for 10 months (Table 1). The inlet and outlet concentrations of $\mathrm{SO}_{2}$ were $100-200 \mathrm{mg} / \mathrm{m}^{3}$ and $0-40 \mathrm{mg} / \mathrm{m}^{3}$, respectively. Flow rate was maintained at $0.6 \mathrm{~m}^{3} / \mathrm{hr}$. Average removal efficiency was only $33.33 \%$ for the first week, then increased gradually. After 24 days of acclimation period, the removal efficiency reached $71.05 \%$. $\mathrm{SO}_{2}$ was completely removed after 5 months, and a maximum elimination capacity of $48.39 \mathrm{~g} / \mathrm{m}^{3} / \mathrm{hr}$ was obtained under an $\mathrm{SO}_{2}$ inlet concentration of $190 \mathrm{mg} / \mathrm{m}^{3}$. Results showed that $\mathrm{SO}_{2}$ could be treated effectively in the thermophilic biofilter.

\subsection{Microbial characteristics}

The microbial populations and their spatial distributions inside the bioreactor can be determined and can serve as an effective tool for understanding and controlling the biological process.

\subsection{1. $\mathrm{SO}_{2}$ degraders in the biofilter}

Microorganisms in the biofilter were analyzed by periodic collection of PUFC. Compared with unused PUFC (Fig. 3a), a large amount of microorganisms accumulated on the surface of PUFC that had been used for 9 months in the thermophilic biofilter (Fig. 3b). Various kinds of microorganisms, including rod-shaped and spherical bacteria, formed the biofilm (Fig. 3c).

Bacteria cells and sulfur bacteria cells in the biofilter were determined by culturing on the proper medium, as described in Section 1.4. After inoculation, $1.52 \times 10^{11} \mathrm{CFUs} / \mathrm{mL}$ of bacteria and $6.87 \times 10^{8} \mathrm{CFUs} / \mathrm{mL}$ of sulfur bacteria were observed in the biofilter (Table 2). A certain number of sulfur bacteria were cultured in the inoculum, and the sulfur bacteria-total bacteria (TB) ratio needed to effectively remove $\mathrm{SO}_{2}$ was $0.45 \%$. Similar to most biosystems, a newly installed biofilter adapts itself to the environment and nutrient supply before efficient biodegradation occurs (Cox et al., 1993). Some amount of microorganisms would disappear during the adaption period because of their inability to adapt to the new environment (Slater and Godwin, 1980). As a result, the amount of TB and sulfur bacteria decreased after inoculation. After 4 months of operation, the amount of TB was sustained from $1.84 \times 10^{10}$ to $3.28 \times 10^{10}$. The amount of total sulfur bacteria (TSB) gradually increased with time after the adaptation period. The ratio of sulfur bacteria to TB markedly increased from $0.45 \%$ to $1.09 \%$ within 10 months. Microbial growth is a consequence of the uptake and metabolism of the pollutants in air. The $\mathrm{SO}_{2}$ in the inlet stream served as an energy source and building material. Bacteria grow vigorously in an environment where food is abundant (Devinny et al., 1999; Shareefdeen and Singh, 2005). Therefore, based on the results of the current study, sulfur bacteria grew rapidly because $\mathrm{SO}_{2}$ was the sole substrate in the biofilter.

\subsubsection{Bacterial structure formed in the biofilter}

DGGE was used to explore the population shifts in response to variation in the biofilter (Fig. 4a). Shannon indices were used to reflect the individual biodiversity of the bacterial groups (Fig. 4a). After the adaption period, the diversity and quantity of TB and TSB decreased with time. Microorganisms participate in the process of microbial degradation through a variety of reactions. Complex substrates lead to the increase of microbial species (Dhamwichukorn et al., 2001). $\mathrm{SO}_{2}$ was the sole substrate in the present study, which resulted in a microbial diversity decrease in the biofilter. Large fluctuations in temperature also led to diversity variation (Kong and Wang, 2013). After

Table 1 - The performance of the thermophilic biofilter.

\begin{tabular}{|c|c|c|c|c|}
\hline $\begin{array}{l}\text { Operation } \\
\text { time (day) }\end{array}$ & $\begin{array}{l}\text { Temperature in } \\
\text { biofilter }\left({ }^{\circ} \mathrm{C}\right)\end{array}$ & $\begin{array}{c}\text { Concentration of } \mathrm{SO}_{2} \\
\left(\mathrm{mg} / \mathrm{m}^{3}\right)\end{array}$ & $\begin{array}{c}\text { Removal efficiency } \\
(\%)\end{array}$ & $\begin{array}{c}\text { Elimination capacity } \\
\left(\mathrm{g} / \mathrm{m}^{3} / \mathrm{hr}\right)\end{array}$ \\
\hline 0 & 50 & - & - & - \\
\hline 7 & 55 & 132 & 33.33 & 33.62 \\
\hline 24 & 50 & 120 & 71.05 & 30.56 \\
\hline 55 & 42 & 175 & 79.10 & 44.57 \\
\hline 76 & 42 & 105 & 86.50 & 26.74 \\
\hline 90 & 40 & 117 & 87.25 & 29.80 \\
\hline 102 & 40 & 105 & 91.67 & 26.74 \\
\hline 120 & 38 & 161 & 89.09 & 41.00 \\
\hline 143 & 42 & 173 & 98.28 & 44.06 \\
\hline 158 & 39 & 126 & 100 & 32.09 \\
\hline 179 & 43 & 158 & 100 & 40.24 \\
\hline 193 & 42 & 170 & 100 & 43.30 \\
\hline 212 & 44 & 190 & 100 & 48.39 \\
\hline 233 & 41 & 190 & 100 & 48.39 \\
\hline 253 & 46 & 176 & 100 & 44.82 \\
\hline 274 & 47 & 161 & 100 & 41.00 \\
\hline 295 & 48 & 190 & 100 & 48.39 \\
\hline 308 & 53 & 190 & 100 & 48.39 \\
\hline
\end{tabular}


a

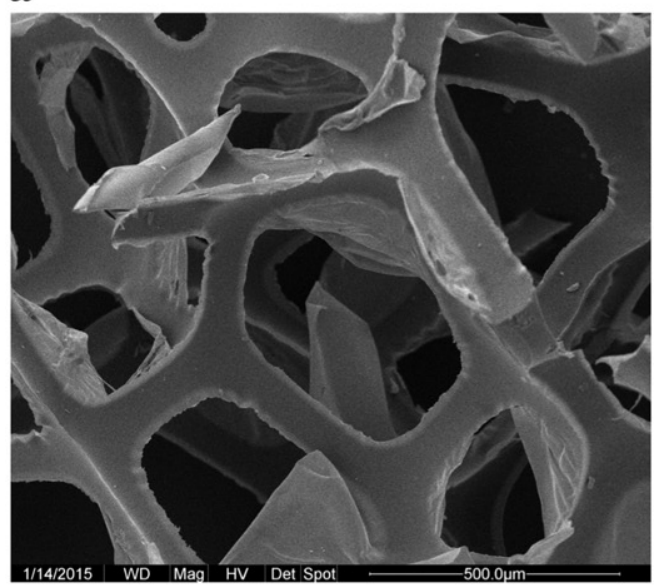

b

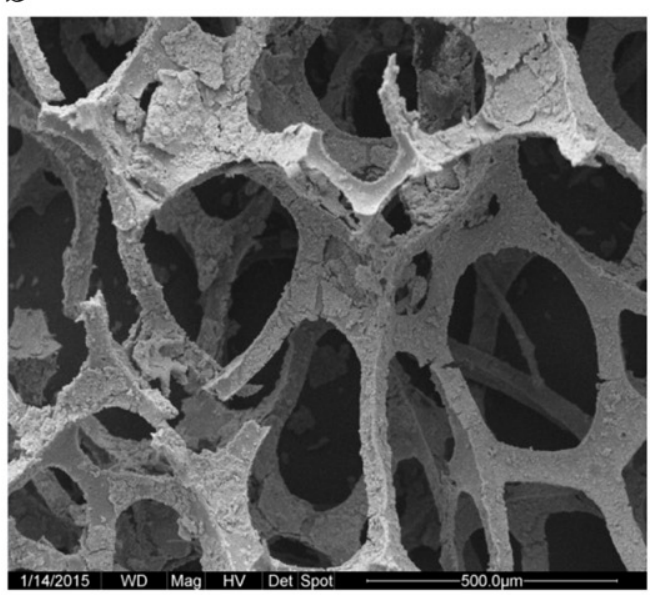

c

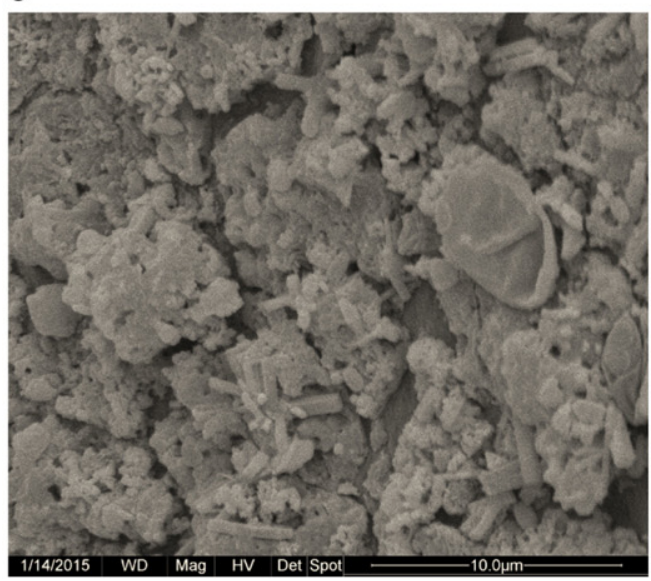

Fig. 3 - Scanning electron microscope (SEM) photos. (a) Surface of unused polyurethane foam cubes (PUFC) $(\times 100)$ (b) Surface of PUFC collected from thermophilic biofilter operated 9 months $(\times 100)$ (c) Surface of PUFC collected from thermophilic biofilter operated 9 months $(\times 5000)$.

308 days of operation, the temperature increased from $47^{\circ} \mathrm{C}$ to $53^{\circ} \mathrm{C}$ and diversity decreased from 2.69 to 2.49 and from 2.60 to 2.29 in samples Y5 and S5, respectively. The genetic evolutionary relationships of bacterial and sulfur bacterial communities are respectively presented in Fig. $4 \mathrm{~b}$ and c. For the bacterial community, Y1 exhibited a close evolutionary relationship to Y2, but was very different from Y5. Y2 and Y5 were collected from the biofilter after 4 and 10 months of operation, respectively. The bacterial population presented obvious temporal variations during the operation period. A similar phenomenon was observed in the sulfur bacterial community.

A total of 16 discriminable bands (B1 to B16) in Fig. 4a that represented the main function bacteria of the microbial community were identified, and their sequences were matched with their closest relatives in GenBank as listed in Table 3. The phylogenetic tree derived from neighbor-joining analysis of partial 16S rRNA gene sequences is shown in Fig. 5. Bands B10, B11, B12, B13, B15, and B16 emerged in all samples, demonstrating that the closest relatives of these bands continually existed in the biofilter. Bands B10 and B11 were closely related to Bacillus circulans (100\%) and Bacillus thermophilus (100\%), respectively. These microorganisms belong to Bacillus sp. and have the ability to remove sulfur-containing compounds under thermophilic conditions (Ryu et al., 2009). Under stressful environmental conditions, Bacillus can produce oval endospores to which the bacteria can reduce themselves and remain in a dormant state for very long periods of time (Madigan and Martinko, 2005). Meanwhile, Band B12 was closely associated with Brevibacillus borstelensis (100\%), a thermophilic bacteria species widely distributed in hot springs, and can use thioanisole as sole carbon and energy source (Li et al., 2015). Bands B13, B15, and B16 belong to Aneurinibacillus sp., which is usually isolated from sludge in high-temperature environments. The strain could degrade sulfide via a biological denitrifying sulfide reaction (Chen et al., 2010). Thermophilic bacteria and desulfurization bacteria existed in the biofilter during the 10 months of operation.

Bands $\mathrm{B} 5$ and $\mathrm{B} 6$ were obvious in all lanes except the inoculum (Y1). Band B5 is affiliated with Acinetobacter sp. (99\%), which is always isolated from soil and sediment samples and is capable of desulfurization (Omri et al., 2011). Band B6 is closely related to Ralstonia sp. (100\%). Several Ralstonia species, such as Ralstonia eutropha, can degrade ethanethiol (Sedighi and Vahabzadeh, 2014).

Bands B4, B7, and B14 appeared at the lane of Y1 (inoculum) but weakened with the increase in operation time. Band B4 exhibited $100 \%$ similarity to Stenotrophomonas humi, and B7 was similar with Desulfitobacterium dichloroeliminans (98\%). They always existed in environments below $40^{\circ} \mathrm{C}$ (Lie et al., 1999; Papizadeh et al., 2011). Microbial activity is strongly influenced by temperature. Each species is adapted to control its own reactions within a certain temperature range. The temperature in the biofilter was maintained at over $40^{\circ} \mathrm{C}$. As the temperature increases, each microbial species reaches a point where it can no longer be effective, and metabolic activity drops off rapidly (Wang et al., 2012). Actually, the Stenotrophomonas humi and Desulfitobacterium dichloroeliminans were killed by the heat and were not present after 4 months. Band B14 is closely associated with Pusillimonas terrae (99\%), which is thermostable but not a desulfurization bacterium (Chénier and Juteau, 2009). $\mathrm{SO}_{2}$ was the sole substrate with high concentration in the biofilter. $\mathrm{SO}_{2}$ may serve as energy source, building material, 
Table 2 - Total bacteria and sulfur bacteria in the biofilter.

\begin{tabular}{llllll}
\multicolumn{1}{c}{ No. } & \multicolumn{1}{c}{ Y1 } & \multicolumn{1}{c}{ Y2 } & \multicolumn{1}{c}{ Y3 } & Y4 \\
\hline Operation time (day) & 0 & 120 & 158 & 233 & 308 \\
TB $($ CFU $/ \mathrm{mL})$ & $1.52 \times 10^{11}$ & $2.28 \times 10^{10}$ & $3.28 \times 10^{10}$ & $1.84 \times 10^{10}$ & $2.54 \times 10^{10}$ \\
TSB $(\mathrm{CFU} / \mathrm{mL})$ & $6.87 \times 10^{8}$ & $6.93 \times 10^{7}$ & $1.11 \times 10^{8}$ & $1.11 \times 10^{8}$ & $2.76 \times 10^{8}$ \\
R $=$ TSB/TB $\times 100 \%$ & 0.45 & 0.3 & 0.34 & 0.6 & 1.09 \\
\hline TB: Total bacteria; TSB: Total sulfur bacteria; R: Ratio. & & & \\
\hline
\end{tabular}

or both to the microorganisms. When microorganisms could not use $\mathrm{SO}_{2}$, the high concentration of $\mathrm{SO}_{2}$ would act like a poison to them.

Desulfurization bacteria and thermophilic bacteria dominated the microbial population in the thermophilic biofilter. The percentages of desulfurization and thermophilic bacteria were $66.7 \%$ and $80.0 \%$, respectively. Microbial growth is a consequence of the uptake and metabolism of air pollutants. The $\mathrm{SO}_{2}$ in the inlet stream functioned as an energy source and building material. The temperature of the biofilter was maintained at 40 to $60^{\circ} \mathrm{C}$ during the operation. Generally, the desulfurization and thermophilic bacteria can vigorously grow in an environment with an abundant food supply and optimal temperature, which maintains the biofilter performance.

\subsection{Oxygen distribution and microbial characteristics in PUFC}

\subsubsection{Oxygen distribution}

A dissolved oxygen (DO) microelectrode was used to investigate oxygen distributions on PUFC with $98.06 \%$ WCR (Fig. 6). DO concentrations were determined along the route that began at position A, as shown in Fig. 6. DO concentration gradually decreased from the surface to the core of the PUFC. A minimum concentration of $0.3 \mathrm{mg} / \mathrm{L}$ could be observed at a position at $4700 \mu \mathrm{m}$ distance from the surface, whereas the concentration in the surrounding air was $9.7 \mathrm{mg} / \mathrm{L}$. The environment may be regarded as anoxic when the DO concentration is under $0.5 \mathrm{mg} / \mathrm{L}$ (Wilen and Balmer, 1998). Therefore, the oxygen distribution presented aerobic-anoxic-aerobic states along the test route on PUFC under the conditions of $98.06 \%$ WCR.

The oxygen transfer from air to liquid phase can be divided into two processes: surface oxygen transfer and liquid film diffusion. Surface oxygen transfer occurs at the air-water interface. The diffusion rate of oxygen in air is only one ten-thousandth of that in water (Cussler, 1997). As a polar molecule, oxygen is poorly soluble in water, inhibiting oxygen transfer through the liquid-gas surface and diffusion in liquid. Therefore, the remarkable change in DO resulted in aerobic-anoxic-aerobic states occurring in PUFC with high WCR. A similar phenomenon was found in the PUFC collected from the biofilter that had been operated for 3 months.
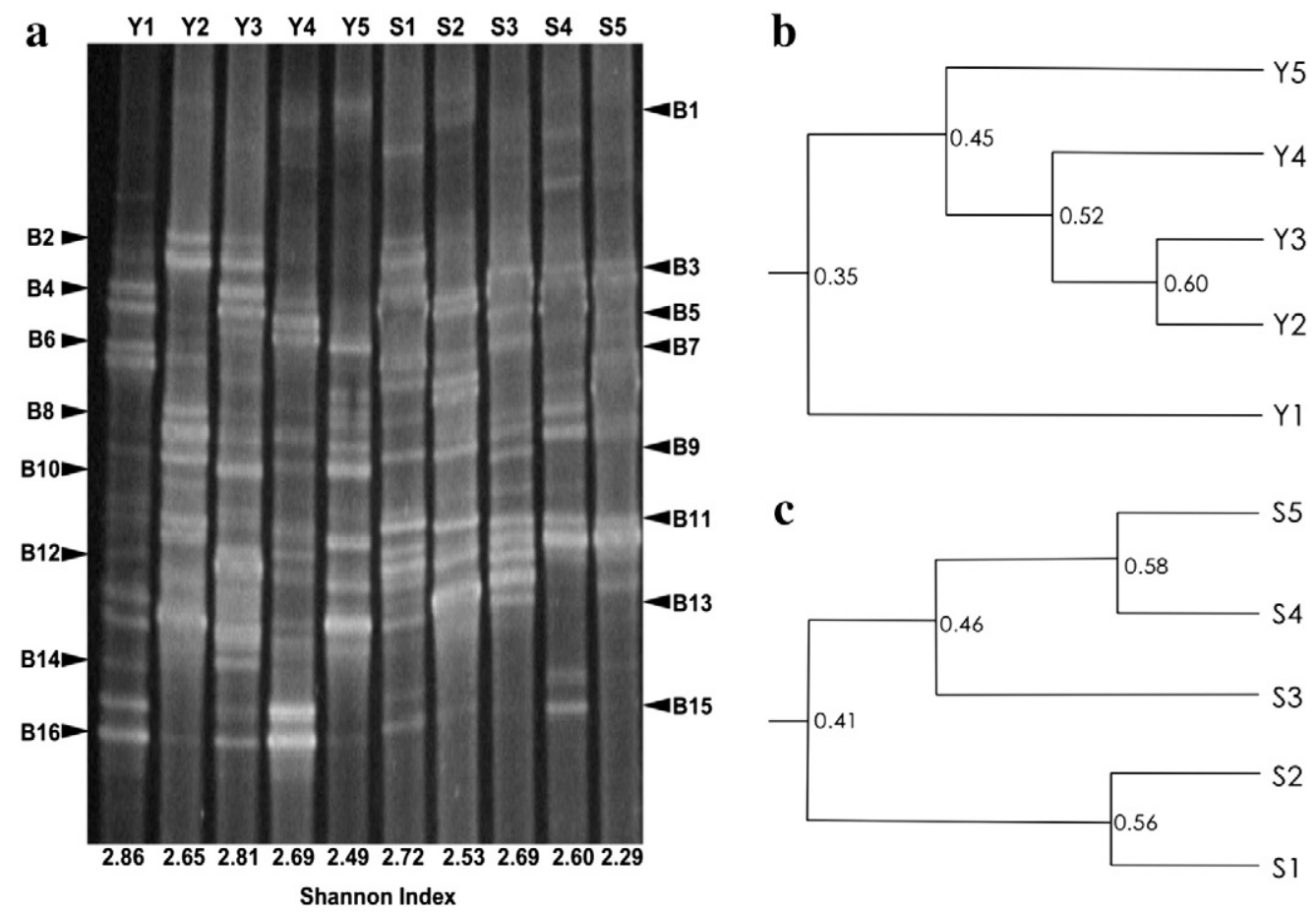

Fig. 4 - (a): DGGE profile and Shannon indices of bacterial community (b): dendrogram of similarity for bacteria (c): Dendrogram of similarity for sulfur bacteria. DGGE: denaturing gradient gel electrophoresis. 


\section{Table 3 - The closest relatives and isolation sources of dominate bacteria.}

\begin{tabular}{|c|c|c|c|}
\hline Band no. & Closest relatives & Source & Similarity \\
\hline B1, B13 & Aneurinibacillus aneurinilyticus G7_2_4BCO2 & $\begin{array}{l}\text { Bacteria; Firmicutes; Bacilli; Bacillales; Paenibacillaceae; } \\
\text { Aneurinibacillus group; Aneurinibacillus. }\end{array}$ & $100 \%$ \\
\hline B2 & Lysinibacillus fusiformis BHR3P1B1 & Bacteria; Firmicutes; Bacilli; Bacillales; Bacillaceae; Lysinibacillus. & $100 \%$ \\
\hline B3 & Clostridium sp. M1 & Bacteria; Firmicutes; Clostridia; Clostridiales; Clostridiaceae; Clostridium. & $100 \%$ \\
\hline B4 & Stenotrophomonas humi KPS-24 & $\begin{array}{l}\text { Bacteria; Proteobacteria; Gammaproteobacteria; Xanthomonadales; } \\
\text { Xanthomonadaceae; Stenotrophomonas. }\end{array}$ & $100 \%$ \\
\hline B5 & Acinetobacter sp. CSeB30_45 & $\begin{array}{l}\text { Bacteria; Proteobacteria; Gammaproteobacteria; Pseudomonadales; } \\
\text { Moraxellaceae; Acinetobacter. }\end{array}$ & $99 \%$ \\
\hline B6 & Ralstonia sp. AF7 & $\begin{array}{l}\text { Bacteria; Proteobacteria; Betaproteobacteria; Burkholderiales; } \\
\text { Burkholderiaceae; Ralstonia. }\end{array}$ & $100 \%$ \\
\hline B7 & Desulfitobacterium dichloroeliminans LMG P-21439 & $\begin{array}{l}\text { Bacteria; Firmicutes; Clostridia; Clostridiales; Peptococcaceae; } \\
\text { Desulfitobacterium. }\end{array}$ & $98 \%$ \\
\hline B8 & Clostridium symbiosum JCM 1297 & Bacteria; Firmicutes; Clostridia; Clostridiales; Lachnospiraceae. & $100 \%$ \\
\hline B9 & Sulfate-reducing bacterium 1-3-5-G4 & Bacteria; environmental samples. & $94 \%$ \\
\hline B10 & Bacillus circulans S1 & Bacteria; Firmicutes; Bacilli; Bacillales; Bacillaceae; Bacillus. & $100 \%$ \\
\hline B11 & Bacillus thermophilus SgZ-10 & Bacteria; Firmicutes; Bacilli; Bacillales; Bacillaceae; Bacillus. & $100 \%$ \\
\hline B12 & Brevibacillus borstelensis 56 & Bacteria; Firmicutes; Bacilli; Bacillales; Paenibacillaceae; Brevibacillus. & $100 \%$ \\
\hline B14 & Pusillimonas terrae EGY-WCP1 & $\begin{array}{l}\text { Bacteria; Proteobacteria; Betaproteobacteria; Burkholderiales; } \\
\text { Alcaligenaceae; Parapusillimonas. }\end{array}$ & $99 \%$ \\
\hline B15, B16 & Aneurinibacillus thermoaerophilus SWCR50_11 & $\begin{array}{l}\text { Bacteria; Firmicutes; Bacilli; Bacillales; Paenibacillaceae; } \\
\text { Aneurinibacillus group; Aneurinibacillus. }\end{array}$ & $99 \%$ \\
\hline
\end{tabular}

\subsubsection{Oxygen distribution and microbial characteristics} Oxygen limitation is more likely to occur in high concentrations of easily degradable hydrophilic compounds (Devinny et al.,
1999). $\mathrm{SO}_{2}$ is a water soluble substance. In this study, the inlet concentration in the biofilter was $100-200 \mathrm{mg} / \mathrm{m}^{3}$. The biofilter was packed with PUFCs, which had $40 \%$ to $90 \%$ of WCR.

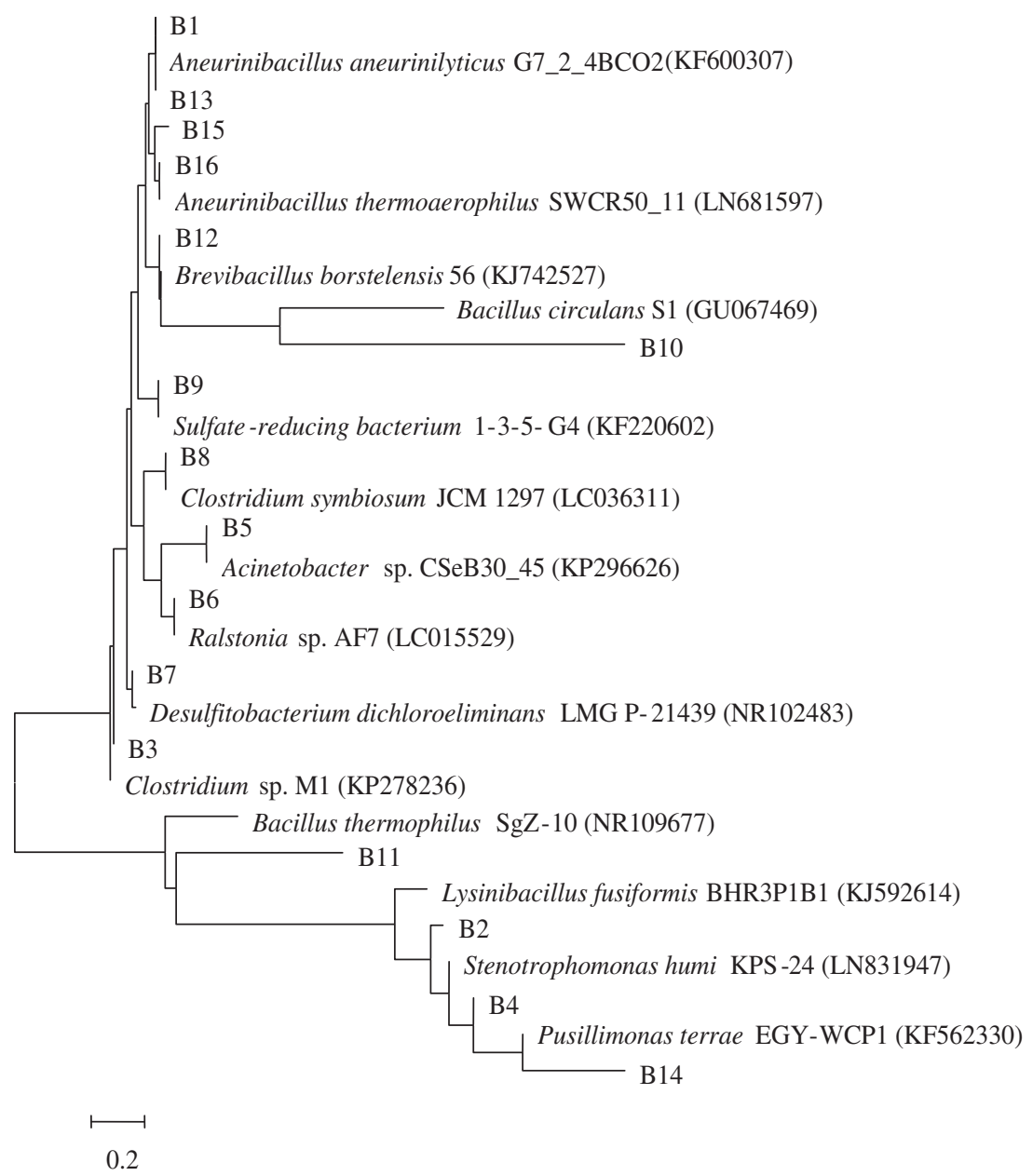

Fig. 5 - The phylogenetic tree derived from neighbor-joining analysis of partial 16S rRNA gene sequences. 


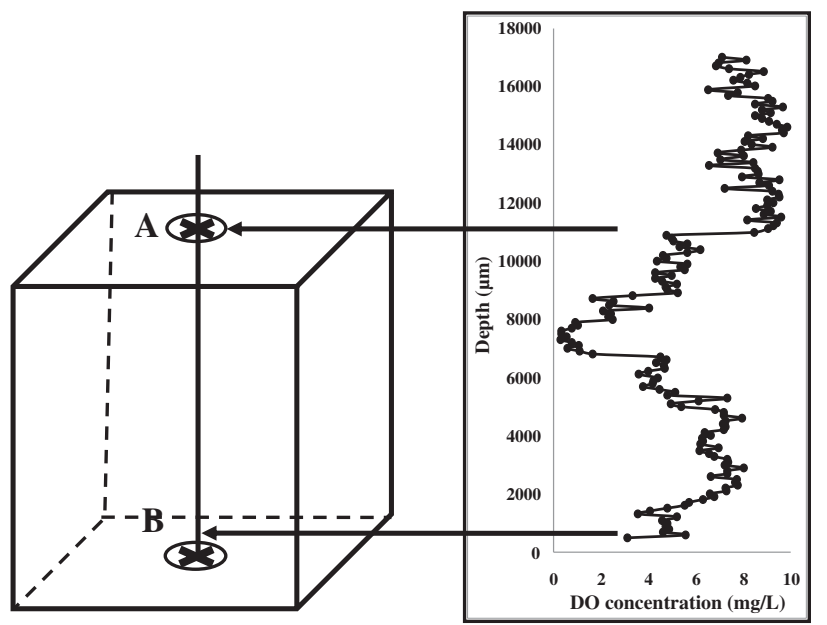

Fig. 6 - Dissolved oxygen (DO) concentration in PUFC.

Although oxygen concentrations in both inlet and outlet of the biofilter were $21 \%$, oxygen deprivation may have occurred at the center of the PUFC with high WCR. Bands B8 and B9, which were closely associated with Clostridium symbiosum (100\%) and sulfate-reducing bacterium (94\%), respectively, were detected after 4 months of operation (Fig. 4a). Clostridium sp. is abundant in sulfide removal systems, and plays a role in sulfide-oxidizing pathways for transforming sulfate $\left(\mathrm{SO}_{4}^{2-}\right)$ to elemental sulfur (Wang et al., 2015). Both of them are anaerobic bacteria and can use $\mathrm{SO}_{4}^{2-}$ as substrate for growth. $\mathrm{SO}_{2}$ was transformed into $\mathrm{SO}_{4}^{2-}$, which accumulated on the PUFCs. The average $\mathrm{SO}_{4}^{2-}$ concentration in the biofilter was $33.73 \mathrm{~g} / \mathrm{L}$. Here, $\mathrm{SO}_{4}^{2-}$ served as an energy provider that was utilized by Clostridium symbiosum and sulfate-reducing bacterium under anoxia conditions. The growth of microorganisms was associated with the environmental conditions and substrate species. The appearance of sulfate-reducing bacterium in the present study was caused by the anaerobic conditions and $\mathrm{SO}_{4}^{2-}$ formation.

\section{Conclusions}

A thermophilic biofilter containing desulfurization bacteria achieved over $90 \% \mathrm{SO}_{2}$ removal efficiency and $48.39 \mathrm{~g} / \mathrm{m}^{3} / \mathrm{hr}$ of maximum elimination capacity at steady state. The microbial population presented temporal variation and relied on the $\mathrm{SO}_{2}$ concentration and environmental conditions formed in the thermophilic biofilter. Results of oxygen detection using microelectrodes indicated that the oxygen concentration shifted along with depth in the PUFC. Aerobic-anoxic-aerobic states were present in PUFC with $98.06 \%$ of WCR. Aerobic bacteria and anaerobic bacteria were all found in the PUFC. The oxygen distribution also influenced the microbial population. Finally, the anaerobic conditions and $\mathrm{SO}_{4}^{2-}$ formation led to the appearance of sulfate-reducing bacteria after 4 months of operation.

\section{Acknowledgments}

The work was supported by the Major Science and Technology Program for Water Pollution Control and Treatment (No.
2010ZX07319-001-03) and the National Natural Science Foundation of China (No. . 51221892).

\section{R E F E R E N C E S}

Allen, E.R., Yang, Y., 1991. Biofiltration Control of Hydrogen Sulfide Emissions, in Proceedings of the 84th Annual Meeting and Exhibition of the Air and Waste Management Association, Air and Waste Management Association. Pittsburgh, PA.

Baltzis, B.C., Androutsopoulou, H., 1994. A Study on the Response of Biofilters to Shock-Loading, in Proceedings of the 87th Annual Meeting and Exhibition of the Air and Waste Management Association, Air and Waste Management Association. Pittsburgh, PA.

Beuger, A.L., Gostomski, P.A., 2009. Development of a biofilter with water content control for research purposes. Chem. Eng. J. 151 (1-3), 89-96.

Chae, K.J., Kim, S.M., Oh, S.E., Ren, X., Lee, J., Kim, I.S., 2012. Spatial distribution and viability of nitrifying, denitrifying and ANAMMOX bacteria in biofilms bioprocess. Biosyst. Eng. 35 (7), 1157-1165.

Chen, C., Wang, A.J., Ren, N.Q., Zhao, Q.L., Liu, L.H., Adav, S.S., et al., 2010. Enhancing denitrifying sulfide removal with functional strains under micro-aerobic condition. Process Biochem. 45 (6), 1007-1010.

Chénier, M.R., Juteau, P., 2009. Fate of chlortetracycline- and tylosin-resistant bacteria in an aerobic thermophilic sequencing batch reactor treating swine waste. Microb. Ecol. 58 (1), 86-97.

Cox, H.H.J., Houtman, J.H.M., Doddema, H.J., Harder, W., 1993. Enrichment of fungi and degradation of styrene in biofilters. Biotechnol. Lett. 15 (7), 737-742

Cox, H.H.J., Sexton, T., Shareefdeen, Z., Deshusses, M.A., 2001. Thermophilic biotrickling filtration of ethanol vapors. Environ. Sci. Technol. 35 (12), 2612-2619.

Cussler, E.L., 1997. Diffusion: Mass Transfer in Fluid Systems. second ed Cambridge University Press, New York.

Degorce-Dumas, J.R., Kowal, S., Le Cloirec, P., 1997. Microbiological oxidation of hydrogen sulphide in a biofilter. Can. J. Microbiol. 43 (3), 264-271.

Devinny, J.S., Deshusses, M.A., Webster, T.S., 1999. Biofiltration for Air Pollution Control. Lewis Publ, New York.

Dhamwichukorn, S., Kleinheinz, G.T., Bagley, S.T., 2001. Thermophilic biofiltration of methanol and a-pinene. J. Ind. Microbiol. Biotechnol. 26 (3), 127-133.

Han, Y.P., Liu, J.X., Guo, X.S., Li, L., 2012. Micro-environment characteristics and microbial communities in activated sludge flocs of different particle size. Bioresour. Technol. 124, 252-258.

Ho, K.L., Chung, Y.C., Lin, Y.H., Tseng, C.P., 2008. Microbial populations analysis and field application of biofilter for the removal of volatile-sulfur compounds from swine wastewater treatment system. J. Hazard. Mater. 152 (2), 580-588.

Jiang, Y.F., Li, S.S., Cheng, Z.W., Zhu, R.Y., Chen, J.M., 2012. Removal characteristics and kinetic analysis of an aerobic vapor-phase bioreactor for hydrophobic alpha-pinene. J. Environ. Sci. 24 (8), 1439-1448.

Kong, X., Wang, C., Ji, M., 2013. Analysis of microbial metabolic characteristics in mesophilic and thermophilic biofilters using Biolog plate technique. Chem. Eng. J. 230, 415-421.

Kong, Z., Farhana, L., Fulthorpe, R.R., Allen, D.G., 2001. Treatment of volatile organic compounds in a biotrickling filter under thermophilic conditions. Environ. Sci. Technol. 35 (21), 4347-4352.

Lee, B.D., Apel, W.A., Smith, W.A., 2001. Oxygen effects on thermophilic microbial populations in biofilters treating nitric oxide containing off-gas streams. Environ. Prog. 20 (3), 157-166. 
Li, G.Y., Liang, Z.S., An, T.C., Zhang, Z.Y., Chen, X.Q., 2015. Efficient bio-deodorization of thioanisole by a novel bacterium Brevibacillus borstelensis GIGAN1 immobilized onto different parking materials in twin biotrickling filter. Bioresour. Technol. 82, 82-88.

Li, L., Han, Y., Liu, J., 2012. Performance and bacterial community diversity of a full-scale biofilter treating leachate odor in a sanitary landfill site. Water Air Soil Pollut. 223 (9), 5599-5611.

Lie, T.J., Godchaux, W., Leadbetter, E.R., 1999. Sulfonates as terminal electron acceptors for growth of sulfite-reducing bacteria (Desulfitobacterium spp.) and sulfate-reducing bacteria: effects of inhibitors of sulfidogenesis. Appl. Environ. Microbiol. 65 (10), 4611-4617.

Madigan, M., Martinko, J., 2005. Brock Biology of Microorganisms. 11th ed. Prentice Hall, London.

Mohammad, B.T., Veiga, M.C., Kennes, C., 2007. Mesophilic and thermophilic biotreatment of BTEX-polluted air in reactors. Biotechnol. Bioeng. 97 (6), 1423-1438.

Nasir, U.P., Brahmaiah, D., 2015. Impact of fireworks on ambient air quality: a case study. Int. J. Environ. Sci. Technol. 12 (4), 1379-1386.

Omri, I., Bouallagui, H., Aouidi, F., Godon, J.J., Hamdi, M., 2011. $\mathrm{H}_{2} \mathrm{~S}$ gas biological removal efficiency and bacterial community diversity in biofilter treating wastewater odor. Bioresour. Technol. 102 (22), 10202-10209.

Ottengraf, S.P.P., 1986. Exhaust gas purification. In: Rehm, H.-J., Reeds, G. (Eds.), Biotechnology 8. VCH verlagsgelsellshaft, Weinheim, pp. 426-452.

Papizadeh, M., Ardakani, M.R., Motamedi, H., Rasouli, I., Zarei, M., 2011. C-S targeted biodegradation of dibenzothiophene by Stenotrophomonas sp. NISOC-04. Appl. Biochem. Biotechnol. 165 (3-4), 938-948.

Ralebitso-Senior, T.K., Senior, E., Di Felice, R., Jarvis, K., 2012. Waste gas biofiltration: advances and limitations of current approaches in microbiology. Environ. Sci. Technol. 46 (16), 8542-8573.

Reynolds, F.E., Grafton, W.D., 1999. Biofiltration: an old technology comes of age. Environ. Technol. 7-8, 51-52.

Ryu, H.W., Yoo, S.K., Choi, J.M., Cho, K.S., Cha, D.K., 2009. Thermophilic biofiltration of H2S and isolation of a thermophilic and heterotrophic H2S-degrading bacterium, Bacillus sp. TSO3. J. Hazard. Mater. 168 (1), 501-506.

Sakuma, T., Jinsiriwanit, S., Hattori, T., Deshusses, M.A., 2008. Removal of ammonia from contaminated air in a biotrickling filter-denitrifying bioreactor combination system. Water Res. 42 (17), 4507-4513.

Saravanan, V., Rajasimman, M., Rajamohan, N., 2015. Performance of packed bed biofilter during transient operating conditions on removal of xylene vapour. Int. J. Environ. Sci. Technol. 12 (5), 1625-1634.

Sedighi, M., Vahabzadeh, F., 2014. Kinetic modeling of cometabolic degradation of ethanethiol and phenol by Ralstonia eutropha. Biotechnol. Bioprocess Eng. 19 (2), 239-249.

Shareefdeen, Z., Singh, A., 2005. Biotechnology for Odor and Air Pollution Control. Springer, Berlin.

Slater, J.H., Godwin, D., 1980. Microbial Adaptation and Selection. In: Hedges, J.N., Latham, M.J., et al. (Eds.), Ellwood DC. Contemporary Microbial Ecology. Academic Press, London.

Stief, P., Schramm, A., Altmann, D., de Beer, D., 2003. Temporal variation of nitrification rates in experimental freshwater sediments enriched with ammonia or nitrite. FEMS Microbiol. Ecol. 46 (1), 63-71.

Tsai, D.G., Lee, D.J., Lai, J.Y., 2008. Oxygen diffusion in single sludge floc. Adv. Powder Technol. 19 (5), 475-481.

Van Groenestijn, J.W., Hesselink, P.G.M., 1993. Biotechniques for air pollution control. Biodegradation 4 (4), 283-301.

Wang, C., Kong, X., Zhang, X.Y., 2012. Mesophilic and thermophilic biofiltration of gaseous toluene in a long-term operation: performance evaluation, biomass accumulation, mass balance analysis and isolation identification. J. Hazard. Mater. 229-230, 94-99.

Wang, X.W., Zhang, Y., Zhou, J.T., Zhang, T.T., Chen, M.X., 2015. Regeneration of elemental sulfur in a simultaneous sulfide and nitrate removal reactor under different dissolved oxygen conditions. Bioresour. Technol. 182, 75-81.

Weerasinghe, S., 2010. A missing values imputation method for time series data: an efficient method to investigate the health effects of sulphur dioxide levels. Environmetrics 21 (2), 162-172.

Wilen, B.M., Balmer, P., 1998. Short term effects of dissolved oxygen concentration on the turbidity of the supernatant of activated sludge. Water Sci. Technol. 38 (3), 25-33.

William, T.O., Miller, F.C., 1992. Biofilters and facility operations. Biocycle 33 (11), 75-79.

Yang, C.P., Chen, H., Zeng, G.M., Zhu, X.Q., Suidan, M.T., 2008. Performance of rotating drum biofilter for volatile organic compound removal at high organic loading rates. J. Environ. Sci. 20 (3), 285-290.

Yang, Y., Allen, E.R., 1994. Biofiltration control of hydrogen sulfide 1. Design and operational parameters. J. Air Waste Manage. Assoc. 44 (7), 863-868.

Zhang, J.Y., Li, L., Liu, J.X., 2015. Thermophilic biofilter for $\mathrm{SO}_{2}$ removal: performance and microbial characteristics. Bioresour. Technol. 180, 106-111. 